\title{
Water Quality Index for the Assessment of Selected Borehole Water Quality in Rivers State
}

\author{
Chinwendu Emeka, Bright Nweke, Jecinta Osere and Chimaobi K. Ihunwo
}

\section{ABSTRACT}

\begin{abstract}
Water quality of different locations in River state, Nigeria was evaluated using Water Quality Index (WQI) approach to assess the suitability of water from three local government areas in Rivers State. The study revealed that WQI was determined by the following parameters: $\mathbf{p H}$, Temp, EC, BOD, Chloride, Sulphate, Calcium, Magnesium, Phosphate, Total Hardness, Nitrate, $\mathrm{Pb}$ Calcium, $\mathrm{Cd}, \mathrm{Cu}$, and $\mathrm{Fe}$. The result obtained indicated that the water quality index of borehole water exceeded the status of water quality in all sampling locations due to groundwater contamination, making the water unsafe for human and animal consumption. Residents within the State should be enlightened on the adverse effect of drinking polluted water and the need for water treatment before consumption.
\end{abstract}

Keywords: Groundwater, Quality Water Index.
Published Online: December 31, 2020

ISSN: $2684-446 \mathrm{X}$

DOI :10.24018/ejgeo.2020.1.6.101

\section{Emeka*}

Rivers State University, Port Harcourt; Nigeria.

(e-mail: chinwendu.emeka1 @ust.edu.ng) B. Nweke

Rivers State University, Port Harcourt; Nigeria.

(e-mail: brightnweke065@gmail.com)

J. Osere

Rivers State University, Port Harcourt,

Nigeria.

(e-mail: oserejecinta@gmail.com)

C.K. Ihunwo

Rivers State University, Port Harcourt,

Nigeria.

(e-mail: chimaobi.ihunwo@ust.edu.ng)

*Corresponding Author

\section{INTRODUCTION}

There are two zones in the underground waters, the vadose and ground water zones, not all underground water are ground water. Ground water whose pressure is less than atmospheric is vadose water while underground water whose pressure is greater than atmospheric is groundwater [11]. Ground water is the major source of drinking water, irrigation, and other domestic activities such as washing, bathing etc. in the Niger Delta region of Nigeria. Groundwater is of abundance and readily available in the abovementioned part of Nigeria, however, the quality of borehole water cannot be visually ascertained unless it is analyzed in the laboratory and compared with relevant standards like WHO and NSDWQ. The activities of human beings can alter the underground water quality during any of the stages of hydrologic or water cycle which comprises of precipitation, surface run-off, infiltration, percolation, evaporation, and transpiration. Infiltration of water through underground rocks, soil may pick- up natural contaminants even with no human activity or pollution in the area. Improper waste management such as indiscriminate dumping of hazardous waste (chemicals, used batteries, paints etc.) in an un-engineered landfill can deter the quality of borehole water. Increase in population density results in rapid increase in the volume of waste generated which may cause serious pollution of underground water [13].

The importance of water cannot be over-emphasized as it plays a significant role in enhancing human life, animal, and plants but if polluted it can be detrimental posing adverse health effect. The study aimed at assessing the selected borehole water in Rivers state using water quality index (WQI) approach [4].

\section{MATERIAL AND METHODS}

\section{A. Study Area}

Obio/Akpor, Etche and Omuma local government areas are located in Rivers State, Nigeria. The sampling location coordinates are given below in Table 1 . The average annual Temperature of the study area was $26.4{ }^{\circ} \mathrm{C}$.

TABLE 1: GEOGRAPHICAL COORDINATES OF THE STUDY LOCATIONS

Sampling Locations Latitude $\quad$ Longitude

Obio/Akpor (EC1) $\quad 4.876556^{\circ} \mathrm{N} \quad 6.920874^{\circ} \mathrm{E}$

$\begin{array}{ccc}\text { Etche }(\mathrm{EC} 2) & 5.0382^{\circ} \mathrm{N} & 7.050636^{\circ} \mathrm{E}\end{array}$

Omuma (EC3) $\quad 5.087575^{\circ} \mathrm{N} \quad 7.231772^{\circ} \mathrm{E}$

\section{B. Sample Collection}

Borehole water samples were taken from different locations within Rivers State. The physical. Chemical and heavy metals were analyzed in line with American Public Health Association [3].

\section{Water Quality Index Calculation}

The WQI was calculated using standards of drinking water quality recommended by the World Health Organization (WHO) and Nigeria Standard of Drinking Water Quality (NSDWQ). The weighted Arithmetic index 
method [4] was used for the calculation of WQI in this study. Further, quality rating or sub index was calculated using the following expression.

$$
q_{n}=100\left[V_{n}-V_{i}\right] /\left[S_{n}-V_{i}\right]
$$

(Let there be $n$ water quality parameters and quality rating $\left(q_{n}\right)$ corresponding to nth parameter is a number reflecting relative value of this parameter in the polluted water with respect to its standard permissible value).

$q_{n}-$ Quality rating for the nth water quality parameter.

$V_{n}$ - Estimated value of the nth parameter at a given water sampling station.

$S_{n}$ - Standard permissible value of the nth parameter

$V_{i}$ - Ideal value of nth parameter in pure water (i.e., 0 for all other parameters except the parameters $\mathrm{pH}$ and Dissolve oxygen [7.0 and $14.6 \mathrm{mg} / \mathrm{l}$ respectively].

The unit weight was calculated by a value inversely proportional to the recommended standard value $\mathrm{Sn}$ of the corresponding parameter.

$$
W_{n}=k / S_{n}
$$

\section{where}

$W_{n}$ - unit weight for nth parameter.

$S_{n}$ - standard permissible value for $n$th parameter.

$k$ - proportionality constant $(\mathrm{K}=1.85445)$.

The overall WQI is calculated by the following equation.

$$
W Q I=\sum q_{n} W_{n} / \sum W_{n}
$$

\section{RESULTS AND DISCUSSION}

Borehole water samples were analyzed to ascertain the extent of ground water pollution. Results were compared with Nigeria Standard for Drinking Water Quality [8] and World Health Organization [14] to determine if it is good for human consumption. The most important physicochemical and heavy metals parameters such as $\mathrm{pH}$, Temperature, Turbidity, Electrical Conductivity (EC), Biological Oxygen Demand (BOD), Chloride, Sulphate, Calcium, Magnesium, Phosphate, Total Hardness, Nitrate, Lead $(\mathrm{Pb})$, Cadmium $(\mathrm{Cd})$, Copper $(\mathrm{Cu})$, and Iron $(\mathrm{Fe})$. borehole water samples were taken at three sampling locations within Rivers State (Obio-Akpor (EC1), Etche (EC2) and Omuma (EC3) Local Government Areas).

\section{A. $p H$ and Temperature}

Water samples in all locations were acidic with $\mathrm{pH}$ values not within the WHO and NSDWQ permissible range. Results from the study area reveals that Temperature for all sampling locations exceeded the acceptable limit of $25^{\circ} \mathrm{C}$ for domestic water, which indicated the presence of foreign bodies like an active micro-organism [9], [1].

\section{B. Copper}

Values obtained showed that copper concentration are less than $0.2 \mathrm{mg} / \mathrm{l}$ were observed in all the locations, however, all the values were below the permissible limit as specified by WHO and NSDWQ. The presence of excess copper in water can result to gastrointestinal disorder when exposed to it for long period.

\section{Lead}

Among the heavy metals, lead is the most significant because it is very toxic and harmful even in small concentration [9], it can harbor in the body tissue causing harm to humans such as cancer, brain damage, mental deficiencies, even death [5]. Concentrations of lead were $0.001 \mathrm{mg} / 1$ in all locations, which indicated that all samples did not exceed the permissive range of $0.01 \mathrm{mg} / \mathrm{l}$ according to WHO and NSDWQ.

\section{Iron}

Iron is known as dark-grey in coloration when in pure form and exists in groundwater as ferric Hydroxide [7]. The concentration of iron in the results obtained were less than $0.1 \mathrm{mg} / \mathrm{l}$ for all locations, which is within the permissible limit of $0.3 \mathrm{mg} / \mathrm{l}$ as specified by WHO. Concentration above the permissible range may be as a result of weathering of minerals and rocks of Iron in the soil, and dissolution of iron natural deposit in groundwater bodies through leaching. Consumption of water containing high concentration of $\mathrm{Fe}$ can cause diabetes, mellitus, liver damage, arteriosclerosis, and other diseases [12] and its toxic even at lower concentration.

\section{E. Cadmium}

The presence of cadmium in ground water occurred when it comes in contact with soil contaminate with discharges from fertilizer industries, paint, petroleum hydrocarbon through leaching. High level of cadmium results to agonistic and antagonistic effects on hormones and enzymes causing several health problems such as kidney failure, cancer etc. [6], [9]. The concentration of $\mathrm{Cd}$ in the study areas are within the WHO and NSDWQ acceptable range.

\section{F. Electrical Conductivity}

EC is the ability of a substance to conduct electric current. This ability depends on the presence of ions, their total concentration mobility, valence, relative concentration and on the temperature. Pure water is not a good conductor of electric current, increase in ion concentration enhances the electrical conductivity of water. The amount of dissolved solids in water determines electrical conductivity. The result indicated the EC value were $114.0 \mu / \mathrm{cm}, 9 \mu / \mathrm{cm}$ and $7.9 \mu / \mathrm{cm}$ for EC1, EC2 and EC3 respectively, this result clearly indicates that water in the study area was not considerably ionized and has lower level of ionic concentration activities.

\section{G. Nitrate}

Nitrate is one of the importance diseases causing parameters of water quality. The sources of nitrate are nitrogen cycle, industrial waste, nitrogenous fertilizer etc. The maximum WHO drinking water limit for nitrate is $10 \mathrm{mgl}$, results from the study areas reveals that the concentration of nitrate in the study areas are $0.631 \mathrm{mg} / \mathrm{l}$, $0.895 \mathrm{mg} / \mathrm{l}$ and $1.58 \mathrm{mg} / \mathrm{l}$ for $\mathrm{EC} 1, \mathrm{EC} 2$ and $\mathrm{EC} 3$, respectively. Values indicated that the Nitrate concentration is within the WHO permissive range. 


\section{H. Chloride}

Chloride is also an important parameter surface water bodies often have low concentration of chloride as compared to groundwater. High concentration of chloride damages metallic pipes and structures, as well causes harm to growing plant through irrigation. Concentration of chloride should not exceed $250 \mathrm{mg} / \mathrm{l}$. Chloride values are $3.04 \mathrm{mg} / 1,8.11 \mathrm{mg} / \mathrm{l}$ and $5.22 \mathrm{mg} / \mathrm{l}$, which indicated that the concentration of Chloride is within the WHO and NSDWQ Permissible range.

\section{Total Hardness}

Total hardness of water is determined by the presence of soluble salts of calcium, magnesium and other heavy metals dissolved in it. Values obtained are within WHO permissive range of $300 \mathrm{mg} / \mathrm{l}$.

\section{J. Turbidity}

Turbidity in drinking water is caused by particulate matter that may be present from sources of water as a result of filtration or from resuspension of sediment in the distribution system. The study revealed that turbidity values of EC1, EC2 and EC3 are within the permissible range of drinking water standard.

\section{K. TDS}

The presence of TDS is an indication of saline water which can be as a result of discharge from industrial treatment plants causing soil contamination leaching effect [2]. The implication of high TDS is reduction in performance of pipes, filters, and valves due to scale accumulation. Values obtained showed that TDS in all locations are $6.003 \mathrm{mg} / \mathrm{l}, 76.04 \mathrm{mg} / \mathrm{l}$ and $42.06 \mathrm{mg} / \mathrm{l}$, which indicated that TDS values are within the WHO and NSDWQ permissible range of $500 \mathrm{mg} / \mathrm{l}$.

\section{L. $B O D$}

BOD gives a measure of oxygen requirement for biodegradation of carbonaceous matter in water

Sample. The BOD values for all sample point are within the acceptable range of $10 \mathrm{mg} / \mathrm{l}$.

\section{M. $D O$}

Dissolved oxygen values for all samples exceeded the WHO and NSDWQ permissible range of $2 \mathrm{mg} / \mathrm{l}$ and $5 \mathrm{mg} / \mathrm{l}$ respectively, the increase of DO may be due to the degree of pollution by organic substance as well as self-purification capacity of the water body.

\section{N. Phosphate and Sulphate}

The concentration of phosphate in all samples was within the permissible range. Phosphates are mostly from fertilizer, industrial cleaning, pesticides while the natural sources include Phosphate containing rock and solid or liquid wastes. Natural water contains sulphate ions and most of these irons are soluble in water. Sulphate concentration in all samples lies within the acceptable limit.

\section{O. Magnesium and Calcium}

Magnesium is usually associated with calcium in all kinds of water, Magnesium is essential for Chlorophyll growth and acts as a limiting factor for the growth of phytoplankton, the depletion of Magnesium reduces the number phytoplankton's population. The amount of calcium in natural water depends on the type of rock. Little concentration of calcium is beneficial in reducing the corrosion in water pipes, the concentration of magnesium in all samples are within the permissible range $75 \mathrm{mg} / \mathrm{l}$ while concentration of calcium in EC1 and EC2 samples exceeded the acceptable standard of WHO and NSDWQ as shown in Table 2 .

TABLE 2: THE PHySICOCHEMICAL PARAMETERS OF SELECTED BOREHOLE WATER SAMPLES AT THREE LOCATIONS

\begin{tabular}{cccccc}
\hline Parameters & EC1 & EC2 & EC3 & WHO, & NSDWQ, \\
& & & & 2011 & 2015 \\
\hline pH & 4.1 & 4.8 & 4.7 & $6.5-8.5$ & $6.5-8.5$ \\
Temp & 28.5 & 28.4 & 27.8 & 25 & - \\
Turbidity & 0 & 1.63 & 0.5 & 5 & 5 \\
EC & 9 & 114 & 79 & 1000 & 1000 \\
TDS & 6.003 & 74.04 & 42.06 & 500 & 500 \\
DO & 6.5 & 7.5 & 7.4 & 2 & 5 \\
BOD & 4.9 & 4.06 & 5.02 & 10 & - \\
Chloride & 3.04 & 8.11 & 5.22 & 250 & 250 \\
Sulphate & 0.001 & 0.001 & 0.001 & 100 & 100 \\
Calcium & 0 & 192 & 90 & 75 & 75 \\
Magnesium & 0 & 8 & 23 & 30 & - \\
Phosphate & 0.001 & 0.001 & 0.001 & 0.1 & - \\
Total Hardness & 0 & 200 & 184 & 300 & - \\
Total Alkalinity & 4 & 18 & 7 & 200 & - \\
Nitrate & 0.631 & 0.895 & 1.58 & 50 & 50 \\
Pb & 0.001 & 0.001 & 0.001 & 0.01 & 0.01 \\
Cd & 0.001 & 0.001 & 0.001 & 0.003 & 0.003 \\
Cu & 0.099 & 0.12 & 0.53 & 2 & - \\
Fe & 0.001 & 0.001 & 0.042 & 0.3 & - \\
\hline
\end{tabular}

\section{P. Total Alkalinity}

Alkalinity is a measure of the buffering capacity to assess the water quality [10]. Results obtained in the study areas are within the WHO permissible range of $200 \mathrm{mg} / \mathrm{l}$.

\begin{tabular}{cccc} 
TABLE 3: CALCULATED WATER QUALITY RATING (QN) OF SELECTED \\
\multicolumn{4}{c}{ BOREHOLE WATER AT THREE LOCATIONS } \\
\hline Parameters & EC1 & EC2 & EC3 \\
\hline pH & 173.33 & 146.67 & 153.33 \\
Temperature & 114 & 113.6 & 111.2 \\
Turbidity & 0 & 32.6 & 10 \\
EC & 0.9 & 11.4 & 7.9 \\
TDS & 1.2 & 15.21 & 8.41 \\
DO & 64.28 & 56.35 & 57.14 \\
BOD & 49 & 40.6 & 50.2 \\
Chloride & 1.22 & 3,24 & 2.09 \\
Sulphate & 0.003 & 0.003 & 0.003 \\
Calcium & 0 & 256 & 120 \\
Magnesium & 0 & 26.7 & 76.7 \\
Phosphate & 1 & 1 & 1 \\
Total Hardness & 0 & 66.67 & 61.33 \\
Total Alkalinity & 2 & 9 & 3.5 \\
Nitrate & 1.26 & 1.79 & 3.16 \\
Pb & 10 & 10 & 10 \\
Cd & 33.3 & 33.3 & 33.3 \\
Cu & 4.95 & 6 & 26.5 \\
Fe & 0.33 & 0.33 & 14 \\
\hline
\end{tabular}


TABLE 4: CALCUlated Unit Weight (WN) OF BOREHOLE WATER SAMPLE AT THREE LOCATIONS

\begin{tabular}{cccc}
\hline Parameters & WHO,2011 & NSDWQ,2015 & Unit Weight (WN) \\
\hline pH & $6.5-8.5$ & $6.5-8.5$ & 0.218 \\
Temperature & 25 & - & 0.074 \\
Turbidity & 5 & 5 & 0.371 \\
EC & 1000 & 1000 & 0.002 \\
TDS & 500 & 500 & 0.004 \\
DO & 2 & 5 & 0.927 \\
BOD & 10 & - & 0.185 \\
Chloride & 250 & 250 & 0.007 \\
Sulphate & 100 & 100 & 0.019 \\
Calcium & 75 & 75 & 0.025 \\
\hline Magnesium & 30 & - & 0.062 \\
Phosphate & 0.1 & - & 18.54 \\
Total Hardness & 300 & - & 0.006 \\
Total Alkalinity & 200 & - & 0.009 \\
Nitrate & 50 & 50 & 0.037 \\
Pb & 0.01 & 0.01 & 185.445 \\
Cd & 0.003 & 0.003 & 618.15 \\
Cu & 2 & - & 0.927 \\
Fe & 0.3 & - & 6.181 \\
\hline
\end{tabular}

TABLE 5: CALCULATED WATER QUALITY INDEX (WQI) FOR BOREHOLE WATER SAMPLES AT THREE SAMPLING LOCATIONS

\begin{tabular}{cc}
\hline $\begin{array}{c}\text { Sampling } \\
\text { Locations }\end{array}$ & Water Quality Index \\
\hline EC1 & 456.773 \\
EC2 & 830.463 \\
EC3 & 749.763 \\
\hline
\end{tabular}

TABLE 6: STATUS OF WATER QUALITY BASED ON WQI [15]

\begin{tabular}{cc}
\hline Water Quality Index & Status \\
\hline $0-25$ & Excellent \\
$26-50$ & Good \\
$51-75$ & Bad \\
$76-100$ & Very Bad \\
100 and above & Unfit \\
\hline
\end{tabular}

\section{CONCLUSION}

The study revealed that borehole water samples collected at three sampling locations EC1, EC2, and EC3 were unsafe for human and animal consumption. Water samples in all sampling locations were acidic with $\mathrm{pH}$.

Dissolved oxygen, temperature, and calcium values not within WHO and NSDWQ permissible range of drinking water standard which demeaned the quality of the water while Turbidity, TDS, BOD, Chloride, Sulphate,

Magnesium, Phosphate, Total Hardness, Total Alkalinity, Nitrate, $\mathrm{Pb}, \mathrm{Cd}, \mathrm{Cu}$ and $\mathrm{Fe}$ were within the $\mathrm{WHO}$ and NSDWQ permissible limit. The study revealed that water quality index values were above the status of water for human and animal consumption. Residence of Rivers state should be enlightened on the adverse effect of drinking polluted water and the need for water treatment before consumption.

\section{REFERENCE}

[1] Akinbile, C. O., and Yusoff, M. S., (2011). Environmental Impact of Leachate Pollution on g groundwater Supplies in Akure, Nigeria.

[2] Boyd, C.E (1999) Water quality: an introduction. Kluwer Academic Publis.ers Group, Dordrecht. ISBN 0-7923-7853-9.

[3] APHA Standard. (2005). Inductively Coupled Plasma/mass Spectrometry Method for Trace Metals. Washington, DC: Amer. 3125B.

[4] Brown, R. M., McCleiland, N. J., Deininger, R. A., and Connor, M. F. O. (1972). A Water Quality Index - crossing the Psychological Barrier (Jenkis, S. H. ed.) Proc. Int. Conf. Water Poll. Res., Jerusalem, 6, $787-797$.

[5] Maddock, B. G. and Taylor, D. (1977). The Acute Toxicity and Bioaccumulation of some Lead Compounds in Marine Animals. In: Lead in the Marine Environment. Proceeding of the International
Experts Discussion on Lead Occurrence, Fate and Pollution in the Marine. Environment, Rovinj, Yugoslavia, 18-22 October, 233 261.

[6] Lewis, R. J. (1991). Hazardous Chemicals Desk Reference (2nd eds), Reinhold: Van Nostrand.

[7] Lekan, T.P, Adeyinka, S.Y. and Tajudeen A.A (October 2019) Assessment of natural groundwater physico-chemical properties in major industrial and residential locations of Lagos metropolis. Applied Water Science 9:191

[8] NSDWQ, (2015). Nigerian Standard for Drinking Water Quality, NIS: 554, 1-28. Oluyemi, E. A., Mak.

[9] Nta, S.A., Ayotamuno M.J., Igoni, A.H., Okparanma, R.N., and Udo, S.O (2020) Determination of Water Quality Index for the Assessment of Groundwater Quality Around Uyo Refuse Dump Site. Umudike Journal of Engineering and Technology 6(1) 49-54.

[10] Gorde, S.P., and Jadhav, M.V. (2013) Assessment of Water Quality Parameters: A Review. International Journal of Engineering Research and Application 3(6) 2029-2035.

[11] Sincero, A P, and Sincero, G, A. (1996) Environmental Engineering: Design Approach.

[12] Brewer, G (2009) Risk of copper and iron toxicity during aging in humans. Chem Res Toxicol 2:319-326.

[13] Adekunle, I. M., Arowolo, T. A., Ndahi, N. P., Bello, B., Owolabi, D. A. (2007) Chemical characteristics of humic acids in relation to Lead, copper and cadmium levels in contaminated soils of Southwest, Nigeria. Annals of Environmental science, North Eastern University, Boston, Massachusetts USA, (1) 23-24.

[14] WHO (World Health Organization) (2011). Guidelines for Drinkingwater Quality. (4TH ed.)-7853-9.

[15] Mishra, P. C. and Patel, R. K. (2001). Quality of Drinking Water in Rourkela, Outside the Steel Township. Env. And Poll. 8:2, 165 169. 